\title{
SEPARATYZM, DZIELNICOWOŚĆ I UNIFIKACJA W II RZECZYPOSPOLITEJ (1918-1939). PROBLEMY INTEGRACJI PAŃSTWA I SPOŁECZEŃSTWA PO ODZYSKANIU NIEPODLEGŁOŚCI
}

\section{Przemysław Olstowski}

http://orcid.org/0000-0002-1379-4407

Instytut Historii im. Tadeusza Manteuffla PAN w Warszawie

ABSTRACT

\section{SEPARATISM, REGIONALISM AND UNIFICATION IN THE SECOND REPUBLIC OF POLAND (1918-1939): PROBLEMS OF THE STATE AND SOCIETY'S INTEGRATION AFTER THE REGAINING OF INDEPENDENCE}

The rebuilding of an independent Polish state after the First World War meant, above all, the urgent necessity of unification of three formerly partitioned lands, especially in context of law, economy and administration. This integration process in the Second Republic as a whole, although long and difficult, was successful. Real problems for the state authorities were separatist tendencies and regional antagonisms. The consequences of more than a hundred years of functioning of three partitioned lands within the Prussian (German), Austrian and Russian states resulted in both national and cultural heterogeneity. Interwar Poland was inhabited by a nationally and ethnically diverse population of various faiths. Germans in former Prussian Poland and in Polish part of Upper Silesia had hopes of rejoining the Reich. Ukrainians in south-eastern districts of Poland wanted to win provincial autonomy and - in the future - their own independent state. Moreover, the social and economic consequences of First World War in different regions of Poland, and the reality of the reborn Polish state, created the ground for conflicts, disappointments, and for regional antagonisms, sometimes even evoking separatist moods, especially in the western provinces. The conundrum of national minorities remained unresolved to the end of the Second Polish Republic in 1939. The question of social and national awareness of members of ethnic groups within the Polish society (Kashubians, Silesians, Masurians), like antagonisms between inhabitants of formerly partitioned lands, was a part of the nation-creating process and integration of the country. The gradual unification of different regional populations within the all-Polish social, cultural, political and economic life in the interwar period was cut short by the outbreak of the Second World War.

Keywords: Second Republic of Poland, home policy, separatism, regionalism, unification, integration processes.

Słowa kluczowe: II Rzeczpospolita, polityka wewnętrzna, separatyzm, dzielnicowość, unifikacja, procesy integracyjne. 
Odzyskanie niepodległości w listopadzie 1918 roku otworzyło trudny proces odbudowy i scalania państwa polskiego z ziem trzech jakże różnych zaborów. Trwającemu do czerwca 1922 roku okresowi budowy terytorialnego kształtu odrodzonej Rzeczypospolitej towarzyszyły zjawiska, które miały istotny wpływ na przyszłe procesy unifikacyjne: a) paryski kongres pokojowy, na którym w znaczącej mierze przesądzono o kształcie granicy zachodniej i północnej, ale też narzucono Polsce postanowienia krępujące politykę narodowościową państwa, zwane małym traktatem wersalskim, b) wojny o granice (a w 1920 r. o zachowanie państwowości), c) walka o władzę w kraju i mające z tym związek spory o kształt ustrojowy państwa.

Unifikację trzech pozaborowych terytoriów (a także Górnego Śląska) w jeden polski organizm państwowy od początku utrudniała spuścizna całego okresu porozbiorowego, o charakterze ustrojowo-prawnym, instytucjonalnym, gospodarczym i - co w dłuższej perspektywie okazało się najistotniejsze - mentalnym. Naczelnik Państwa Józef Piłsudski miał tego pełną świadomość, przemawiając na uroczystym obiedzie w sali Magistratu w Lublinie 11 stycznia 1920 roku:

Moi panowie! Jednym z przekleństw naszego życia, jednym z przekleństw naszego budownictwa państwowego jest to, żeśmy się podzielili na kilka rodzajów Polaków, że mówimy jednym polskim językiem, a inaczej nawet słowa polskie rozumiemy, żeśmy wychowali wśród siebie Polaków różnych gatunków, Polaków z trudnością się porozumiewających, Polaków tak przyzwyczajonych do życia według obcych szablonów, według obcych narzuconych sposobów życia i metod postępowania, żeśmy prawie je za swoje uznali, że wyrzec się ich z trudnością możemy. [...] Sprawa zjednoczenia wszystkich dzielnic Polski nie jest jeszcze zakończona, a zjednoczona Ojczyzna jest często jeszcze słowem, a nie tą realną rzeczywistością. Polska, jeżeli chce być silną nie na uroczystościach, nie przy kielichu wina, lecz w codziennej pracy, w codziennym życiu, w codziennych wspólnych kłopotach, w codziennym słuchaniu ogólnych i zjednoczonych praw, Polska musi być zjednoczona i Polska musi być jednością ${ }^{1}$.

W słowach tych pobrzmiewała zarówno konieczność zjednoczenia ziem polskich, tj. ich integracji prawno-ustrojowej, instytucjonalnej, gospodarczej i kulturalnej, jak i najważniejsze związane z tym problemy. To ostatnie odnosiło się również do zagadnień ujętych w tytule niniejszego artykułu. Co więcej, nad wyraz trafnie określało ich zasadnicze przyczyny. O wiele bardziej bowiem tkwiły one w obszarze różnic mentalnych i politycznych niźli ustrojowo-prawnych. Co nie znaczy, że te ostatnie nie miały swojej wagi, zwłaszcza w pierwszych latach istnienia Polski Odrodzonej, na które przypadła zasadnicza część procesów unifikacyjnych w wymiarze instytucjonalnym i prawno-ustrojowym i w których przezwyciężano najważniejsze związane z nimi problemy.

Podstawową sprawą była unifikacja administracji państwowej ogólnej i niezespolonej w wymiarze instytucjonalnym i prawnym. Państwo musiało bowiem funkcjonować według określonego wzorca. Dokonano tego możliwie sprawnie, choć nie bez ustępstw na rzecz tych rozwiązań instytucjonalnych, których dalsze istnienie

${ }^{1}$ J. Piłsudski, Pisma zbiorowe. Wydanie prac dotychczas drukiem ogłoszonych, t. V, Warszawa 1937, s. 136-137. Powyższym cytatem rozpoczął niegdyś swój artykuł J. Kutta, ,My” $i$,,oni” na Pomorzu w latach 1920-1939. Przyczynek do dziejów integracji spoteczeństwa polskiego, „Zapiski Historyczne" 1991 , t. 56 , z. 2-3, s. 59. 
uznano za korzystne. Tak więc po unifikacji byłej dzielnicy pruskiej (1919-1922) pozostawiono w obu jej województwach (poznańskim i pomorskim) partykularyzmy ustrojowe będące spuścizną po ustroju pruskim, w szczególności w zakresie kolegialnego zarządzania $\mathrm{w}$ urzędach wojewódzkich oraz sądownictwa administracyjnego na szczeblu wojewódzkim i powiatowym ${ }^{2}$. Niektóre $\mathrm{z}$ nich pozostawiono też potem w rozporządzeniu Prezydenta Rzeczypospolitej Polskiej z 28 stycznia 1928 roku o organizacji i zakresie działania władz administracji ogólnej ${ }^{3}$, unifikującym ustrój administracji ogólnej w skali całego kraju.

II Rzeczpospolita była państwem unitarnym. Wyjątkiem od tej normy ustrojowej było województwo śląskie, cieszące się autonomią (w tym własnym sejmem śląskim, policją i skarbem) opartą na śląskim statucie organicznym z 15 lipca 1920 roku, uchwalonym przez Sejm Ustawodawczy w formie ustawy konstytucyjnej ${ }^{4}$. Próby narzucenia Polsce autonomii dla trzech województw Małopolski Wschodniej (lwowskiego, stanisławowskiego i tarnopolskiego), z przyczyn natury zasadniczej wyznaczanych racją stanu państwa, nie doszły do skutku. Dlatego też Ustawa z 26 września 1922 roku o zasadach powszechnego samorządu wojewódzkiego, a w szczególności województwa lwowskiego, tarnopolskiego i stanisławowskiego ${ }^{5}$, nie bez kozery nazywana wtedy w Sejmie RP „ustawą eksportową” z myślą o przyszłej decyzji Rady Ambasadorów w sprawie uznania wschodniej granicy Rzeczypospolitej (powziętej ostatecznie 15 marca 1923 r.), nigdy nie weszła w życie. Z kolei wzgląd na kwestie polityki wewnętrznej, ale i pewne rachuby na poprawę stosunków polsko-litewskich mimo inkorporacji Litwy Środkowej do Polski w 1922 roku zdecydowały o przejściowym zachowaniu w latach 1922-1926 odrębnego statusu ziemi wileńskiej jako okręgu administracyjnego na czele $\mathrm{z}$ delegatem rządu, nim na mocy ustawy sejmowej z 22 grudnia 1925 roku stała się z dniem 20 stycznia 1926 roku województwem wileńskim ${ }^{6}$.

Choć konstytucja Rzeczypospolitej Polskiej z 17 marca 1921 roku przewidywała możliwość zorganizowania samorządu wojewódzkiego w całym kraju, to jednak istniał on jedynie w obu województwach byłej dzielnicy pruskiej: poznańskim i pomorskim, a wywodził się z dawnego pruskiego samorządu prowincjonalnego. W Małopolsce Wschodniej i Zachodniej do 1928 roku istniała zaś namiastka takiego samorządu w postaci Tymczasowego Wydziału Samorządowego. Władze centralne nie zamierzały rozszerzać zasięgu tego szczebla samorządu poza obszar byłej dzielnicy pruskiej, z jednej strony z powodu niewysokiej oceny funkcjonowania samorządu powiatowego i gminnego $w$ dawnych zaborach rosyjskim i austriackim, $z$ drugiej ze względu na stosunki narodowościowe, przede wszystkim w województwach południowo-wschodnich, tj. we wschodniej Małopolsce i na Wołyniu. Mniej chodziło tu o uprawnienia samorządu wojewódzkiego - nie tak małe, ale przecież subsydiarne

${ }^{2}$ Szerzej o tym w odniesieniu do spraw unifikacji administracji i samorządu: A. Tarnowska, Z dziejów unifikacji administracji II Rzeczypospolitej. Rola przepisów pruskich, Torun 2012.

3 Dz.U. RP 1928, nr 11, poz. 86.

${ }^{4}$ Dz.U. RP 1920, nr 73, poz. 497.

${ }_{5}^{5}$ Dz.U. RP 1922, nr 90, poz. 829.

${ }^{6}$ Dz.U. RP 1926, nr 6, poz. 29. 
w stosunku do działań i uprawnień państwa - a bardziej o to, że w oczach polityków ukraińskich mógłby uchodzić za etap na drodze ku autonomii tych województw. Dlatego też w Ustawie z 23 marca 1933 roku o częściowej zmianie ustroju samorządu terytorialnego ${ }^{7}$, unifikującej ustrój samorządu - do tej pory funkcjonującego zasadniczo odmiennie w trzech byłych zaborach - na szczeblach powiatu i gminy, nie wprowadzono zapisów o utworzeniu samorządu wojewódzkiego w skali kraju, pozostawiając go w województwach poznańskim i pomorskim. Zachowanie na tym obszarze samorządu wojewódzkiego świadczyło o uznaniu go przez władze za właściwy w warunkach byłej dzielnicy pruskiej ${ }^{8}$. W tym sensie ów partykularyzm ustrojowy, łącznie ze wspomnianym wyżej sądownictwem administracyjnym w województwach poznańskim, pomorskim, a następnie i śląskim, nie miał charakteru antyunifikacyjnego, przeciwnie, świadczył o docenieniu roli nowoczesnych pruskich form ustrojowych dla życia politycznego, społecznego i gospodarczego w tych dzielnicach. Inaczej było w przypadku śląskiego statutu organicznego z 15 lipca 1920 roku i konwencji genewskiej z 15 maja 1922 roku, które - tu badacze są zgodni - w wielu istotnych dziedzinach były czynnikami hamującymi integrację polskiej części Górnego Śląska z Rzeczpospolitą, co zaczęło powoli, ale konsekwentnie ulegać zmianie po maju 1926 roku9 . Choć przecież śląski statut organiczny uchwalony został z myślą o Górnoślązakach, by zachęcić ich do głosowania za Polską w przewidywanym plebiscycie, konwencja genewska miała umożliwić sprawne funkcjonowanie górnośląskiego obszaru przemysłowego po jego podziale po zakończeniu III powstania śląskiego, pomiędzy Polskę i Niemcy.

Obok możliwie jednolitego ustroju administracji terytorialnej i samorządu, istotnym obiektem działań unifikacyjnych było prawo. Dzięki pracy Komisji Kodyfikacyjnej do końca istnienia II RP doprowadzono do zunifikowania prawa karnego i części obszarów prawa cywilnego, a także gospodarczego ${ }^{10}$. Unifikacja (od 1919 r. stanowiących jedność po włączeniu do Wojska Polskiego sił zbrojnych byłego zaboru pruskiego) oraz Policji Państwowej stała się faktem po zakończeniu wojen o niepodległość i granice. Mimo to pełna integracja w obrębie obu tych formacji, zwłaszcza jednak wojska, nie dokonała się do końca II RP. Problem ten dotyczył zresztą wielu innych dziedzin życia państwowego, społecznego i gospodarczego. Po prostu zabrakło czasu.

O ile proces unifikacji instytucjonalnej i prawnej - choć trudny i na wielu polach niezakończony do 1939 roku - nie budzi w zasadzie sporów w zakresie jego

7 Dz.U. RP 1933, nr 35, poz. 294.

${ }^{8}$ P. O1stow ski, Samorzad terytorialny $w$ województwie pomorskim $w$ latach II Rzeczypospolitej [w:] Pomorskie - twarza do przyszłości. 20 lat samorzadu terytorialnego w III Rzeczypospolitej, red. G. Grzelak, Gdańsk 2018, s. 55-69.

9 Por. M.W. Wa na to w i z, Wrastanie w Polskę. Z problemów unifikacji i integracji Górnego Ślaska z Druga Rzeczapospolita [w:] Górny Śląsk po podziale w 1922 roku. Co Polska, a co Niemcy daty mieszkańcom tej ziemi?, t. 1, red. Z. Kapała, W. Lesiuk, M.W. Wan a towicz, Bytom 1997, s. 204-207; eadem, Województwo ślaskie na tle Drugiej Rzeczypospolitej [w:] Województwo ślaskie (1922-1939). Zarys monograficzny, red. F. S er a fin, Katowice 1996, s. 28.

${ }^{10}$ Por. ogólnie: J. B arda ch, B. Leśn od ors ki, M. Pietrzak, Historia ustroju i prawa polskiego, Warszawa 2001, s. 552-555. 
pojmowania, o tyle tytułowe pojęcia „separatyzm” i „dzielnicowość” są w odniesieniu do okresu II RP zarówno nieostre, jak i obciążone nieporozumieniami. Dotyczy to także - choć w o wiele mniejszym stopniu - obocznego w stosunku do nich pojęcia „partykularyzm”, a nawet „regionalizm”. Dążenia o charakterze ściśle separatystycznym oczywiście istniały w całym okresie II RP, mimo aktywności władz, integracyjnej roli szkoły i wojska oraz powolnego zrastania się trzech byłych zaborów pod względem gospodarczym i kulturalnym ${ }^{11}$. Wynikały z dziedzictwa pozaborowego, ale były też pochodną procesu scalania ziem polskich po I wojnie światowej. W skład II RP - bądź decyzją zwycięskich mocarstw, bądź manu milita$r i$ - weszły bowiem obszary będące poza Królestwem Polskim i zachodnią Galicją przedmiotem aspiracji innych narodów (Ukraińcy, Litwini, Białorusini, Czesi) albo obiektem aspiracji polskich do ziem przedrozbiorowych (zabór pruski) oraz tych zamieszkałych przez ludność polską bądź pochodzenia polskiego (Mazury, Górny Śląsk), które w skład dawnej Rzeczypospolitej nie wchodziły. Spore grupy ludności czuły się więc związane $\mathrm{z}$ tradycją poprzednich organizmów państwowych (zwłaszcza Niemcy w byłych zaborach pruskim i austriackim oraz na Górnym Śląsku, co w wypadku dawnych obywateli Rzeszy powodowało dążenie do powrotu w jej granice), odczuwały związek z nowo powstałymi (Litwini), zerkały w stronę Związku Sowieckiego z powodów ekonomicznych (część ludności białoruskiej, ukraińskiej i szeroko rozumianej „tutejszej” na Kresach Wschodnich), pragnęły na zamieszkanych przez nią obszarach II RP utworzenia podstaw własnego państwa (Ukraińcy) bądź przyłączenia do już istniejącego (Litwini). Ciążyła nad tym pamięć niedawnych konfliktów zbrojnych o Górny Śląsk, Wielkopolskę, Małopolskę Wschodnią, Wileńszczyznę, a na ziemiach wschodnich - wojny polsko-sowieckiej 1919-1920 roku, której wynik przesądził o przynależności państwowej tych obszarów, co dla większości ich niepolskiej ludności - wyłączając nawet kontestujących polską państwowość Ukraińców wschodniogalicyjskich i Litwinów - nie musiało być powodem do radości z przyczyn o charakterze kulturowym, ale i ze względu na wspomnianą już pamięć niedawnych wydarzeń z lat 1919-1920.

Posiadanie przez II RP silnych liczebnie mniejszości narodowych, w niemałej części przejawiających tendencje odśrodkowe i gotowych kontestować polską państwowość, powodowało wsparcie dla ich działań przez oba nieprzyjazne Polsce organizmy państwowe - Niemcy i Związek Sowiecki. Działania sowieckie w pierwszej połowie lat 20. w największym stopniu polegały na destabilizacji sytuacji wewnętrznej na terenie województw wschodnich poprzez akcję dywersyjną o charakterze zbrojnym ${ }^{12}$, a w późniejszym okresie już głównie o charakterze propagandowym,

11 Proces integracji dokonywał się również wewnątrz poszczególnych zaborów, choć niekiedy było to trudne, jak w dawnym zaborze rosyjskim w odniesieniu do obszaru byłego Królestwa Polskiego i Ziem Zabranych.

${ }^{12}$ Por. W. Śleszyński, Bezpieczeństwo wewnętrzne w polityce państwa polskiego na ziemiach pótnocno-wschodnich II Rzeczypospolitej, Warszawa 2007; J.J. Bruski, Między prometeizmem a realpolitik. II Rzeczpospolita wobec Ukrainy Sowieckiej 1921-1926, Kraków 2011; P. Ci ch or ack i, Stotpce - Łowcza - Leśna 1924. II Rzeczpospolita wobec najpoważniejszych incydentów zbrojnych w województwach pólnocno-wschodnich, Łomianki 2012. 
także z wykorzystaniem audycji radiowych. Obok tego do początku lat 30. propaganda miała też wymiar instytucjonalny o charakterze quasi-narodowym poprzez stworzenie odpowiednio w Mińsku oraz Kijowie i Charkowie białoruskiego i ukraińskiego centrum narodowo-kulturalnego, mającego oddziaływać na te społeczności na terenie Rzeczypospolitej i wzmacniać przez to tendencje odśrodkowe. W latach 20. służyć temu miało także powołanie tzw. polskich rejonów narodowościowych na Ukrainie i Białorusi sowieckiej, niezależnie od związanych z nimi, do czasu, planów bardziej dalekosiężnych.

Z kolei Niemcy, które podobnie jak ZSRS nie pogodziły się z porządkiem wersalskim i będącymi jego pochodną rozstrzygnięciami terytorialnymi, wspierały w latach 20. i 30., z rozmaitym natężeniem, narodową irredentę ukraińską, a także ukraińskie ugrupowania polityczne z natury rzeczy nieprzyjazne polskiej państwowości, ale działające legalnie i z przyczyn natury zasadniczej, po upadku nadziei na rozwiązanie autonomiczne (a wcześniej otwartej kontestacji państwa polskiego), szukające modus vivendi $\mathrm{z}$ władzami polskimi. Przede wszystkim jednak Niemcy stanowiły oparcie dla mniejszości niemieckiej w Polsce, jakiego nie mogła mieć żadna inna mniejszość narodowa w naszym kraju, niezależnie nawet od tego, że mały traktat wersalski i konwencja górnośląska z 1922 roku dawały Niemcom w Polsce możliwość wnoszenia skarg na forum Ligi Narodów. W drugiej połowie lat 20. Niemcy, dzięki umiejętnemu wykorzystaniu przewagi w relacjach gospodarczych i stosunkach międzynarodowych, potrafiły doprowadzić do wstrzymania wydalania optantów przez Polskę (1925), a następnie zalegalizowania dalszego ich pobytu (1929). Dzięki swej pozycji ekonomicznej i stałej, choć z różnym natężeniem płynącej pomocy finansowej z Berlina oraz wsparciu politycznemu ze strony Rzeszy, mniejszość niemiecka była dla władz polskich tyleż wyzwaniem, co niemożliwym do rozwiązania problemem. Potrafiła też, dzięki długoletnim powiązaniom lokalnym, oddziaływać kulturowo na rdzenną ludność polską na terenie dzielnic zachodnich, co mogło być niebezpieczne w kontekście procesów integracyjnych w obrębie społeczeństwa polskiego.

Od początku też - tj. od 1919 roku - władze w Berlinie ograniczały rozmiar exodusu ludności niemieckiej z Wielkopolski i Pomorza po ogłoszeniu decyzji traktatu wersalskiego, tak by zachować na przyszłość podstawy do żądań rewindykacyjnych, przede wszystkim w odniesieniu do Pomorza, skutecznie określonego przez niemiecką propagandę mianem korytarza. Ludność niemiecka, niemożliwa w swej masie do zasymilowania (licząca około 800000 osób w 1939 r.), a najsilniejsza liczebnie i strukturalnie na terenie województw zachodnich, ze względów politycznych, kulturowych i wyznaniowych, pozostawała w życiu społecznym II RP czynnikiem odrębnym, funkcjonując na uboczu życia polskiego, ale nie bez kontaktów z ludnością polską. Obok poczucia narodowego, zwłaszcza w byłym zaborze pruskim i na Górnym Śląsku, w szczególnym stopniu spajał ją czynnik kulturowy, obok języka i u większości osób wyznania (ewangelicko-unijnego) decydujący o odrębności w stosunku do polskiego otoczenia. Do końca istnienia II RP pozostawała czynnikiem odśrodkowym, choć jej grupy przywódcze po 1934 roku oficjalnie manifestowały lojalność wobec państwa polskiego. Tendencje odśrodkowe w jej obrębie 
w największym stopniu przejawiały się w okresie istnienia w latach 1921-1923 Niemieckiego Związku dla Ochrony Praw Mniejszości w Polsce (Deutschtumsbund zur Wahrung der Minderheitsrechte in Polen), będącego swego rodzaju państwem w państwie, mającego w założeniu być ekspozyturą państwa niemieckiego w Polsce, reprezentującą Niemców wobec państwa polskiego i organizującą ich obok tego państwa, a faktycznie w kontrze do niego ${ }^{13} \mathrm{i}$ będącą oparciem dla próbujących prezentować podobne postawy Ukraińców i Litwinów. W gruncie rzeczy Deutschtumsbund uprawiał separatyzm w dosłownym znaczeniu. Powstałe po jego likwidacji w 1923 roku kolejne reprezentacje polityczne mniejszości niemieckiej w Polsce - Zjednoczenie Niemieckie w Sejmie i w Senacie (Deutsche Vereinigung in Sejm und Senat) działające w latach 1923-1930, a z kolei od 1934 roku Zjednoczenie Niemieckie (Deutsche Vereinigung) jako quasi-partia polityczna, pozostające w konsekwentnej opozycji do państwa polskiego, choć próbujące być państwowo lojalnymi, ów separatyzm mniej lub bardziej zręcznie ukrywały. Podobnie po 1922 roku zachowywał się Volksbund w województwie śląskim. Rozwiązanie Deutschtumsbundu przez władze polskie w 1923 roku wpłynęło jednak na uspokojenie nastrojów, z czasem także wśród wspieranej przezeń mniejszości ukraińskiej.

W przypadku mniejszości białoruskiej dużym zaskoczeniem dla władz polskich była ujawniona niebawem po maju 1926 roku skala jej narodowych aspiracji, objawiona w postaci Białoruskiej Robotniczo-Włościańskiej Hromady ${ }^{14}$. Żywiołowość rozwoju struktur i radykalizm jej żądań społecznych i narodowych spowodowały, w obawie przed dalszym rozwojem wpływów, rozwiązanie Hromady przez władze państwowe w marcu 1927 roku i nieliczenie się przez nie z prawem przy likwidacji ruchu hromadzkiego. Autorytaryzm obozu władzy spowodował, że aspiracje społeczności białoruskiej nie objawiały się już więcej tak otwarcie, a radykalizm objawiał się w działalności nielegalnej Komunistycznej Partii Zachodniej Białorusi. Osobne w tym kontekście i wymagające dalszych badań pozostaje zjawisko „tutejszości”.

Zamkniętą w sobie społecznością powiązaną z Kownem pozostali Litwini, ale ich separatyzm, ze względu na niewielką liczebność, nie był dla władz problemem. Takim było wypracowanie stosunku do najsilniejszego na Kresach Wschodnich ruchu ukraińskiego. Nie było tutaj na dłuższą metę dobrego wyjścia, ani w postaci „polityki wołyńskiej” Henryka Józewskiego (niezależnie od jej roli w stosunkach polsko-sowieckich), ani $\mathrm{w}$ postaci modus vivendi $\mathrm{z}$ Ukraińskim Zjednoczeniem Narodowo-Demokratycznym (UNDO) w Małopolsce Wschodniej. W obawie przed widmem ,galicyjskiego Piemontu” nie chciano nawet stonować restrykcji wobec organizacyjnych form ukraińskiego życia społecznego i kulturalnego, nie mówiąc już

${ }^{13}$ Por. Deutsche und Polen zwischen den Kriegen. Minderheitenstatus und "Volkstumskampf" im Grenzgebiet (1920-1939). Amtliche Berichterstattung aus beiden Ländern 1920-1939, hrsg. R. Jaworski, M. Wojciechowski, bearb. M. Niendorf, P. Hauser, München - New Providence - London - Paris 1997, s. 298-303 (pismo wojewody pomorskiego Jana Brejskiego do starostów z 19 VI 1923 w sprawie kontynuowania działalności przez Deutschtumsbund).

${ }_{14}$ Por. J. Januszewska-Jurkiewicz, Stosunki narodowościowe na Wileńszczyźnie $w$ latach 1920-1939, Katowice 2010, s. 610-619; E. Kirwiel, Kresy Pótnocno-Wschodnie Rzeczypospolitej Polskiej w latach 1918-1939. Oblicze polityczne, Lublin 2011, s. 121. 
o autonomii, która w dodatku prowokowałaby krytykę ze strony polskiego obozu narodowego i wzrost podobnych tendencji w województwach zachodnich, w tym w obrębie mniejszości niemieckiej. Faktycznym miernikiem stosunków polsko-ukraińskich w ostatnich latach II RP pozostał zatem wzrost wpływów i liczebności Organizacji Ukraińskich Nacjonalistów, a wyrazem tendencji władz państwowych i wojskowych - akcja burzenia cerkwi prawosławnych w ziemi chełmskiej i na Podlasiu w latach 1937-1939.

Ów irredentystyczny potencjał wśród najbardziej wyrazistych kulturowo mniejszości narodowych powodował, że procesy integracyjne w społeczeństwie II RP w największym stopniu zachodziły w obrębie społeczeństwa polskiego. Wpłynął też znacząco na centralistyczny i unitarny charakter państwa, którego władze miały świadomość odśrodkowych aspiracji w obrębie mniejszości terytorialnych. Dlatego nie mogło być w nim miejsca dla tendencji autonomicznych, a wszelkie ich przejawy pozostające poza kontrolą władz państwowych, także w postaci regionalnych ruchów społeczno-kulturalnych, rodziły podejrzenia o separatyzm. Nie było to jednak takie proste. Tym bardziej że o ile tendencje odśrodkowe w obrębie mniejszości narodowych były efektem ich dążeń o charakterze politycznym i kulturalnym, a w wypadku mniejszości słowiańskich także społecznym, o tyle odruchy (bo tak to trzeba nazwać) separatystyczne w obrębie zachodnich społeczności polskich bądź z Polakami szczepowo związanych (jak część Kaszubów i Górnoślązaków czy Mazurzy działdowscy) wynikały zasadniczo z kwestii społecznej, podobnie jak kwestią społeczną była w dużym stopniu sama niepodległość Polski po I wojnie światowej. Oczywiście, pożywką dla tendencji bliskich separatyzmowi, bardziej o charakterze emocjonalnym niż stricte politycznym, były społeczne koszta włączenia dzielnic zachodnich, zwłaszcza Pomorza z subregionem kaszubskim oraz Śląska Górnego i części Cieszyńskiego, do Rzeczypospolitej. Także poczucie swojszczyzny i kulturowej obcości w stosunku do Polaków z innych dzielnic w połączeniu z bliskością kultury niemieckiej, tej codziennej, nie zaś wysokiej. Powodowało to, że grupy niechętne państwowości polskiej istniały w obrębie społeczeństwa polskiego zawsze, jednak każdorazowy wzrost ich znaczenia wiązał się z problemami gospodarczymi i społecznymi, a te trapiły II RP z różnym natężeniem przez cały okres jej istnienia, szczególnie jednak w pierwszej połowie każdej z dwu dekad jej niepodległego bytu.

Osobną kwestią była dzielnicowość i nastroje dzielnicowe. Inną jeszcze regionalizm. Podkreślenia wymaga tu kilka zasadniczych spraw. Wszystkie wymienione zjawiska były dziedzictwem epoki porozbiorowej, a w wypadku byłej dzielnicy pruskiej także kształtowania się stosunków społecznych, gospodarczych i kulturowych jeszcze w średniowieczu i w czasach dawnej Rzeczypospolitej. Regionalizm, w sensie kulturowej swoistości, istniał z różną wyrazistością we wszystkich dzielnicach odrodzonej Polski. O ile jednak w byłym Królestwie Polskim, Galicji (także wschodniej) i na Kresach Wschodnich był to zasadniczo regionalizm etnograficzny, o tyle w byłej dzielnicy pruskiej i województwie śląskim (odrębnie na Śląsku Górnym i Cieszyńskim) występowała dzielnicowość w sensie politycznym i kulturowym, na bazie której ruch regionalny o charakterze kulturalnym wyłonił się w dalszej kolejności i podobnie jak w innych dzielnicach, miał w latach 30. charakter regionalizmu 
tworzonego w znacznej mierze przez władze państwowe, choć eksplorowanego tu i przez opozycję, głównie obóz narodowy ${ }^{15}$. Warto przy tym zauważyć istotną dla trwałości i rozwoju regionalizmu, a także tendencji dzielnicowych, rolę inteligencji, zarówno miejscowej, jak i napływowej. Wbrew pozorom wpływ przedstawicieli tej ostatniej, szczególnie galicyjskiej, na kształtowanie się nastrojów i postaw dzielnicowych w zachodniej Polsce nie powinien dziwić. Wyrosła ona bowiem w Galicji w dobie autonomii. Stanisław Wachowiak, Wielkopolanin, podsekretarz stanu w Ministerstwie byłej Dzielnicy Pruskiej (1920-1922) i ostatni przedmajowy wojewoda pomorski (1924-1926), nie bez kozery poczynił po latach następujące spostrzeżenie:

Jest dla mnie rzeczą dziwną, że wszyscy bez mała urzędnicy wysokich stopni służbowych, rekrutujący się przeważnie z Małopolan, zwykle stawali się większymi dzielnicowcami niż tubylcy, autochtoni. Stwierdzam ten fakt jako psychologicznie interesujący, chociaż ktoś bardzo mądry powiedział mi, że było to naturalne. Habeat sibi ${ }^{16}$.

Najwyraźniej silna potrzeba identyfikacji z nowym miejscem (regionem) zamieszkania, tak wyrazista wśród inteligencji pochodzącej ze wschodniej i zachodniej Małopolski, mogła prowadzić niejednokrotnie do utożsamiania się z hasłami dzielnicowymi bazującymi na poczuciu swojskości i kulturowej odrębności ludności miejscowej.

Dzielnicowość w województwach zachodnich - poza, jak wspomniałem, stosunkowo nielicznymi środowiskami - nie była tożsama z separatyzmem, nawet jeśli treść agitacji dzielnicowej mogła na to wskazywać. Formułowane z perspektywy warszawskiej oskarżenia o separatyzm poznański, pomorski (kaszubski) i śląski miały zasadniczo charakter polityczny, przede wszystkim w okresie istnienia tzw. państwa komisariackiego w Wielkopolsce, czyli rządów Komisariatu Naczelnej Rady Ludowej w Poznaniu, a następnie w Poznańskiem i na Pomorzu w trakcie zamachu majowego i pierwszych miesięcy po jego przeprowadzeniu ${ }^{17}$. Oczywiście, tendencje separatystyczne na Kaszubach, wśród Mazurów w powiecie działdowskim oraz na Górnym Śląsku i Śląsku Cieszyńskim istniały, mając za podstawę trwałą niechęć pewnej liczby mieszkańców do państwa polskiego, ale na znaczeniu zyskiwały w szczególnie dramatycznych okresach kryzysu gospodarczego i w tym sensie były zasadniczo kwestią socjalną. Nastroje dzielnicowe zaś, bazujące na subiektywnym poczuciu kulturowej odrębności i wyższości oraz lepszej jakości życia publicznego, były zjawiskiem trwałym, a na Pomorzu (szczególnie na Kaszubach) i na Górnym Śląsku były także efektem wspomnianych wyżej społecznych kosztów integracji z Polską ${ }^{18}$. Towarzyszył

${ }^{15}$ Rzecz warta dalszych, głębokich badań, wykraczających poza ziemie zachodnie II Rzeczypospolitej, por. B. Wy s ock a, Regionalizm wielkopolski w II Rzeczypospolitej 1919-1939, Poznań 1981.

${ }_{16}$ S. Wachowiak, Czasy, które przeżyłem, Warszawa 1991, s. 55.

${ }^{17}$ Inaczej postrzega to, szczególnie w odniesieniu do pierwszych lat niepodległości, J. Kutta, Separatyzm i dzielnicowość w Wielkopolsce i na Pomorzu w latach 1918-1926, Warszawa 1979 (praca doktorska obroniona w Instytucie Historii PAN).

${ }^{18}$ Por. A. Czubiński, Problem tzw. separatyzmu dzielnicowego w Wielkopolsce i na Pomorzu w latach 1918-1926 [w:] Pomorze i Wielkopolska po odzyskaniu niepodlegtości w 1918 roku, red. S. Gierszewski, Gdańsk 1983, s. 54-70; E. Kopeć, Poludniowo-zachodnie kresy Rzeczypospolitej 1918-1939. Spoleczne warunki integracji, Katowice 1981; idem, „My” i „oni” na polskim Ślasku 
temu „upadek mitu Polski zamożnej i sprawiedliwej”. Nastroje dzielnicowe i związane z nimi negatywne stereotypy w odniesieniu do ludności napływowej były zatem mówiąc za Januszem Kuttą w odniesieniu do Pomorza i Kaszub - rodzajem „rekompensaty za stracone złudzenia i spadek poziomu życia gospodarczego" 19 , ale i za subiektywne odczucie - zwłaszcza po maju 1926 roku - „polityki nierówności i dyskryminacji miejscowego elementu, a także [za] zdradę obietnicy nieskrępowanego awansu społecznego w polskim państwie narodowym"20. Udrożnieniu kanałów awansu społecznego dla ludności miejscowej, szczególnie na Górnym Śląsku, nie sprzyjała jednak podnoszona przez badaczy „nieprzystawalność struktur społecznych” wobec braku w województwie śląskim własnej inteligencji oraz - w odróżnieniu od Pomorza klasy średniej, tworzonej na Górnym Śląsku przez przybyszów ${ }^{21}$. Tendencje separatystyczne, a w odniesieniu do ludności polskiej dzielnicowe, niebezpieczne dla Polski, słabły w obliczu postępów polityki integracji ziem trzech byłych zaborów. Tyle że II RP istniała jednak za krótko, by efekty tej polityki mogły się pełniej ujawnić.

\section{BIBLIOGRAFIA}

Bardach J., Leśnodorski B., Pietrzak M., Historia ustroju i prawa polskiego, Warszawa 2001.

Brusk i J.J., Między prometeizmem a realpolitik. II Rzeczpospolita wobec Ukrainy Sowieckiej 1921-1926, Kraków 2011.

Cichoracki P., Stołpce - Łowcza - Leśna 1924. II Rzeczpospolita wobec najpoważniejszych incydentów zbrojnych w województwach pótnocno-wschodnich, Łomianki 2012.

Czubiński A., Problem tzw. separatyzmu dzielnicowego w Wielkopolsce i na Pomorzu w latach 1918-1926 [w:] Pomorze i Wielkopolska po odzyskaniu niepodległości $w 1918$ roku, red. S. Giers zew ski, Gdańsk 1983.

Deutsche und Polen zwischen den Kriegen. Minderheitenstatus und „Volkstumskampf” im Grenzgebiet (1920-1939). Amtliche Berichterstattung aus beiden Ländern 1920-1939, hrsg. R. Jaw orski, M. Wojciechowski, bearb. M. Niendorf, P. Hauser, München-New Providence-London-Paris 1997.

Januszewska-Jurkiewicz J., Stosunki narodowościowe na Wileńszczyźnie $w$ latach 1920-1939, Katowice 2010.

Kirwiel E., Kresy Pólnocno-Wschodnie Rzeczypospolitej Polskiej w latach 1918-1939. Oblicze polityczne, Lublin 2011.

Ko peć E., „,My” i ,oni” na polskim Śląsku (1918-1939), Katowice 1986.

Kopeć E., Południowo-zachodnie kresy Rzeczypospolitej 1918-1939. Społeczne warunki integracji, Katowice 1981.

(1918-1939), Katowice 1986; Regionalizm a separatyzm - historia i wspótczesność. Ślask na tle innych obszarów, red. M.W. Wan a tow ic z, Katowice 1995; J. Kutta, Druga Rzeczpospolita i Kaszubi 1920 1939, Bydgoszcz 2003.

19 J. Kutta, ,My” $i$,,oni” na Pomorzu w latach 1920-1939, s. 75.

${ }^{20}$ Ibidem, s. 72.

${ }^{21}$ Por. M.W. Wa na to w i c z, Ludność napływowa na Górnym Śląsku w latach 1922-1939, Katowice 1982, s. 276-284. 
Kutta J., „,My” $i$,oni” na Pomorzu w latach 1920-1939. Przyczynek do dziejów integracji społeczeństwa polskiego, „Zapiski Historyczne” 1991, t. 56, z. 2-3, s. 59-83.

Kutta J., Druga Rzeczpospolita i Kaszubi 1920-1939, Bydgoszcz 2003.

Kutta J., Separatyzm i dzielnicowość w Wielkopolsce i na Pomorzu w latach 1918-1926, Warszawa 1979 (praca doktorska obroniona w Instytucie Historii PAN).

Olstowski P., Samorząd terytorialny $w$ województwie pomorskim w latach II Rzeczypospolitej [w:] Pomorskie - twarza do przyszłości. 20 lat samorzadu terytorialnego w III Rzeczypospolitej, red. G. Grzelak, Gdańsk 2018, s. 55-69.

Piłsudski J., Pisma zbiorowe. Wydanie prac dotychczas drukiem ogłoszonych, t. V, Warszawa 1937.

Regionalizm a separatyzm - historia $i$ współczesność. Ślask na tle innych obszarów, red. M.W. Wanatowicz, Katowice 1995.

Śleszyński W., Bezpieczeństwo wewnętrzne w polityce państwa polskiego na ziemiach pótnocno-wschodnich II Rzeczypospolitej, Warszawa 2007.

Tarnow s ka A., Z dziejów unifikacji administracji II Rzeczypospolitej. Rola przepisów pruskich, Toruń 2012.

Wachowiak S., Czasy, które przeżytem, Warszawa 1991.

Wanatowicz M.W., Ludność naptywowa na Górnym Ślasku w latach 1922-1939, Katowice 1982.

Wa na to w i c z M.W., Województwo śląskie na tle Drugiej Rzeczypospolitej [w:] Województwo śląskie (1922-1939). Zarys monograficzny, red. F. S e rafin, Katowice 1996.

Wa na to w i c z M.W., Wrastanie w Polskę. Z problemów unifikacji i integracji Górnego Ślaska z Druga Rzeczapospolita [w:] Górny Ślask po podziale w 1922 roku. Co Polska, a co Niemcy dały mieszkańcom tej ziemi?, red. Z. Kapała, W. Lesiuk, M.W. Wan atowicz, t. 1, Bytom 1997.

Wy so cka B., Regionalizm wielkopolski w II Rzeczypospolitej 1919-1939, Poznań 1981. 